\title{
Analysis of Competition and Complementarity in the BRICS Export Products
}

\author{
Pei-Zhi WANG ${ }^{1, a}$, Yu-Xin ZHAO ${ }^{1, b,{ }^{*}}$, Ling-Xi CHU ${ }^{1, c}$ \\ ${ }^{1}$ Shandong University of Finance and Economics, Jinan, China \\ awpzmail@126.com, ${ }^{\mathrm{b}} 723797175 @ q q . c o m,{ }^{c} \mathrm{clx} 0459 @ 163 . c o m$
}

\begin{abstract}
Keywords: BRICS, Revealed comparative advantage, Export trade, Competition, Complementarity.
\end{abstract}

\begin{abstract}
BRICS are representatives of emerging economies. Since twenty-first Century, Brazil, China, India, Russia and South Africa have developed rapidly and become leaders in developing countries. It is of great significance to study on the trade between the BRICS countries. This paper based on the Ricardo's comparative advantage theory, using the revealed comparative advantage index as the analysis tool, and collecting the BRICS countries exports data from 2010 to 2015, analyzing the competition and complementary between the BRICS countries; it is shown that there is competition and complementary between the BRICS countries export products; Finally giving some advises for the BRICS countries export trade.
\end{abstract}

\section{Introduction}

Since the reform and opening up, China's rapid economic development has become an important driver of world economic growth, at the same time, the connection with the world economy is becoming closer, The total amount of the imports and exports is increasingly growing. It surpassed Germany to become the world's largest exporter by 2010 and surpassed the United States to become the world's number one foreign trade country by 2013.

In addition, in the 21st century, because of rapid economic development, Brazil, India, Russia and South Africa, together with China, have become leaders in emerging economies and developing countries. In 2001, the concept of "BRIC" was first proposed by Goldman Sachs in the world and included the four largest emerging market countries in the world. In November 2010, the Group of Twenty's meeting was held in Seoul, and South Africa applied for joining the "BRICS" at this meeting. Since then, "BRIC" officially formed and renamed "BRIC countries." The "BRICS", as the world's most representative emerging economies, are the one of the force in determining the global economic pattern. The notion of "BRICS" and the emergence of their cooperation mechanism are the inevitable products of the changes in the current world economic pattern.

Much of the literature on the competitiveness and complementarity of BRICS export products focuses on a specific study of a particular category of products. Wenjing Yin (2016) analyzed the competitiveness and complementarity of China's trade with other BRICS in agricultural products, she thought the competitiveness was greater than complementarity, and the trade integration was increasingly closer. Ya Zhang (2016) mainly studied the trade between China and other BRIC countries in the agricultural products industry. Baichuan Sang (2014) analyzed the the competitiveness and complementarity of China with other BRICS in service trade. In the study of the overall competitiveness and complementarity of BRICS, Yujuan Huang (2015) used the TC index and RCA index to analyze the trade competitiveness of BRIC countries in detail, and simply analyzed the trade complementarities .

Based on the above research background, this paper chooses "BRICS" as the research object, analyzes the "BRICS" status of the main export products in recent years, and uses the revealed comparative advantage index to analyze the competitiveness of export products. According to the specific data of the "BRICS" import and export products, this paper also analyzes the complementarities between the BRICS industries trades and the intra-industry trades. Finally, this paper provides the reasonable suggestions for the future development and trade cooperation of 
BRICS countries.

\section{Model}

This paper studies the competitiveness and complementarities of BRICS export products, and uses the comparative advantage theory to analyze them. Suppose there are only two production factors: labor and capital.

In order to understand the comparative advantages of export products in a country or region, this paper selects the revealed comparative advantage index (RCA ) to calculate the comparative advantage of the export products. The revealed comparative advantage index, also known as export performance index, is used to analyze the comparative advantage in a product, it is a ratio between a country's exports of certain products account for its share of total exports and the world exports of certain products account for its share of total exports. The ratio can reflect the relative export situation of various industries in a country. The formula is as follows:

$$
R C A_{\mathrm{ij}}=\frac{\frac{X_{\mathrm{ij}}}{X_{\mathrm{it}}}}{\frac{X_{\mathrm{wj}}}{X_{\mathrm{wt}}}}
$$

$X_{\mathrm{ij}}$ is the export product of $\mathrm{j}$ in the country $\mathrm{i}, X_{\mathrm{it}}$ is the total export products in the country i. $X_{\mathrm{wj}}$ is the export product of $\mathrm{j}$ in the whole world, $X_{\mathrm{wt}}$ is the total export products in the whole world. In general, RCA index close to 1 means neutrality, there is no relative advantage or disadvantage. RCA index greater than 1 means that the export share of this product in the country is greater than its share in the world, so this country in the product has the comparative advantages in the world market. If the RCA index is less than 1 , it means that there is no comparative advantage in the world market and the competitiveness is relatively weaker. If there are many countries have a RCA index greater than 1, it means that the competition is fierce between these countries in the world market. When the similarities between the countries export products are small, it means that there is no competition between the countries export products, so the countries have highly complementary.[1]

The revealed comparative advantage index is a method adopted by the American economist Bela Parasa in calculating the comparative advantage of some international trade in 1965. This method eliminates the influence of the national total fluctuation and the world total fluctuation, and reflects the comparative advantage of export products between the country and the world. It is not characterized by directly analyzing the determinants of comparative advantage or trade structure, but by indirectly determining the comparative advantage from the result of the import and export products.

\section{Data Analysis}

\section{China Export Product Profile}

Since the reform and opening up, China's economy develops rapidly, and foreign exchange is gradually increasing. Since its entry into the 21st century, China join to the World Trade Organization, it means that China foreign trade comes to a new stage. With the progress of economic globalization, China connect with the world economy closely, and China's economy more and more depends on the world market. At the same time, its position in the world market is becoming more and more important, and its competitiveness is more and more strong. Therefore, the export volume of China's foreign trade is increasing year by year with the expansion of opening to the outside world and the development of economic globalization.

As shown in Figure 1.1, in 2014, the total value of China's imports and exports was 26.43 trillion 
yuan, up 2.3\% over the same period of last year, the total amount of exports was 14.39 trillion yuan, up $4.9 \%$ and the total amount of imports was 12.04 trillion yuan, down $0.6 \%$, trade surplus 2.35 trillion yuan, an increase of $45.9 \%$. In 2015, with the sluggish overall global economic recovery, the total volume of China's trade in goods also reached 24.59 trillion yuan, down $7 \%$ from 2014, the amount of the export was 14.14 trillion yuan, down $1.8 \%$. the amount of the import was 10.45 trillion yuan, down 13.2\%; the trade surplus was 3.69 trillion yuan, expanding 56.7\%.

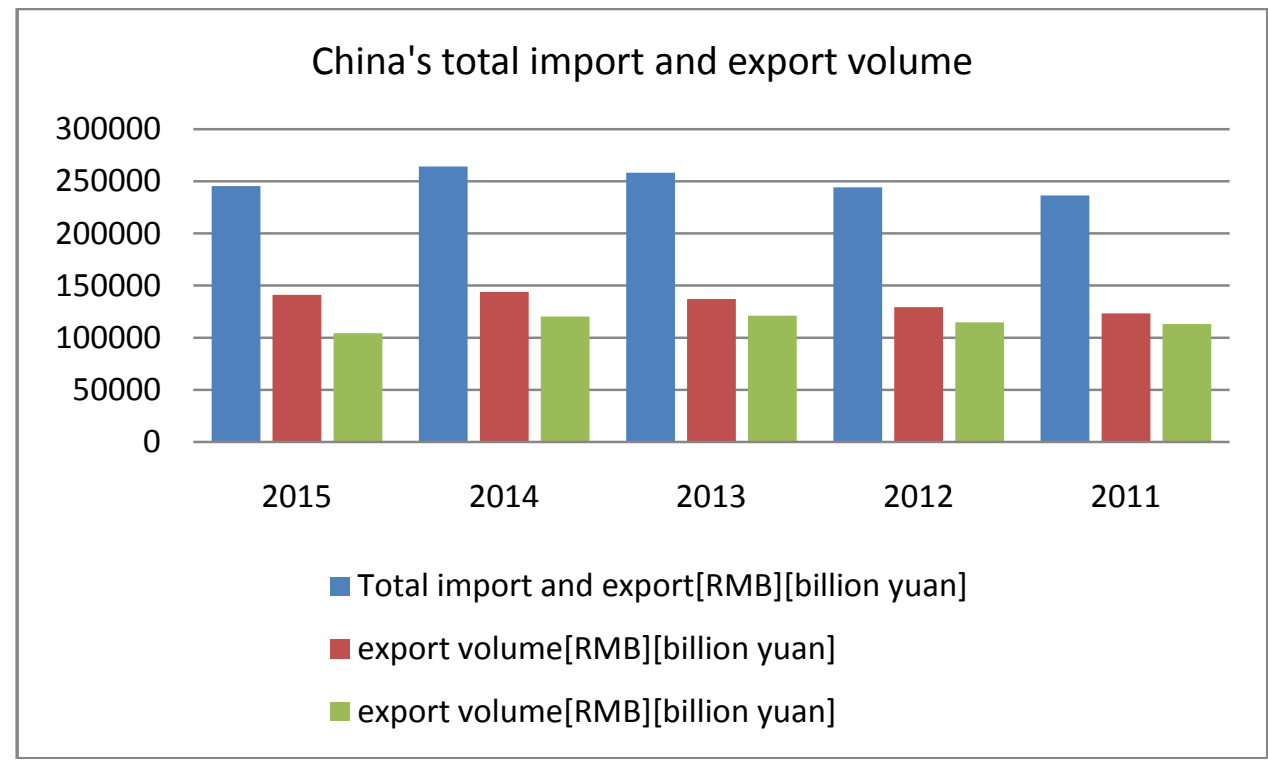

Figure 1.1: China's total import and export volume **Data Sources: National Bureau of Statistics of China

With the improvement of China's economic strength and the expansion of foreign trade, the competitiveness of China's export products in the world market has been enhanced. At the same time, the structure of China's export products has also undergone slight changes.

Table 1-1: China revealed comparative advantage index

\begin{tabular}{|l|l|l|l|l|l|l|l|l|}
\hline & Clothing & Textile & Food & $\begin{array}{l}\text { Animals } \\
\text { plants }\end{array}$ & $\begin{array}{l}\text { Machinery } \\
\text { Electronics }\end{array}$ & Steel & Transportation & $\begin{array}{l}\text { Chemical } \\
\text { industry }\end{array}$ \\
\hline 2010 & 3.552 & 2.953 & 0.381 & 0.367 & 1.487 & 0.905 & 0.550 & 0.497 \\
\hline 2011 & 3.543 & 3.100 & 0.385 & 0.375 & 1.516 & 1.015 & 0.584 & 0.554 \\
\hline 2012 & 3.435 & 3.039 & 0.371 & 0.362 & 1.514 & 1.002 & 0.543 & 0.523 \\
\hline 2013 & 3.312 & 3.007 & 0.355 & 0.347 & 1.504 & 1.044 & 0.471 & 0.515 \\
\hline 2014 & 3.133 & 2.884 & 0.347 & 0.342 & 1.423 & 1.243 & 0.454 & 0.531 \\
\hline
\end{tabular}

**Data Sources: YaQin Chen. Trade Complementarity Between China and One Belt and One Road Countries_—Based on Chronological Data Analysis with Comparative Advantage[J].Journal of Jixi University, 2016(10).

As shown in Table 1-1, RCA index is greater than 1 in the types of clothing, textile, machinery electronics and steel, indicating that China's share of exports in clothing, textile, machinery electronics and steel products greater than the world's share of exports in these products, then these types of products in the international market has comparative advantages, so these products have the international competitiveness. But RCA index is less than 1 in the types of food, animal and plant products, transportation equipment and chemical products, indicating that China's share of exports in food, animal and plant products, transportation equipment and chemical products less 
than the world's share of exports in these products, then these types of products in the international market has not comparative advantages, so these products have not the international competitiveness. At the same time, food products and textile products, as typical labor-intensive products, account for a large proportion of labor-intensive products. China has a comparative advantage on food products and textile products, indicating that China is still mainly exporting labor-intensive products, this is based on the fact that China has a large population base and labor costs are cheaper. On the steel products, the RCA index in China shows an upward trend, indicating that China's capital-intensive product exports are also gradually developing and expanding, and there is great room for growth in accelerating economic restructuring.

\section{Other BRIC Countries Export Product Profile}

\section{Brazil}

Brazil located in the South America, it is the largest country in South America with abundant natural resources and a complete industrial base. Its GDP ranks first in South America and ranks as the seventh largest economy in the world. After its economy stagnated in 2014, Brazil suffered a political and economic crisis in 2015. However, as a BRICs member, Brazil remains an important part of global governance. Brazil's industrial development ranks first in Latin America, and a relatively complete industrial system was built in the 1970s. Steel, shipbuilding, automobile and aircraft manufacturing have all been among the world's major producers. At the same time, agriculture and animal husbandry in Brazil are also very developed. Brazil is the major producers and exporters of sucrose, coffee, soybeans and corn.

As Figure 2.1 shows, in recent years, Brazil exports mainly food exports and manufactured exports, these products account for more than $70 \%$ of Brazil's main export products, and have been rising gradually over the years. It is related to rich natural resources and advanced industrial system. In terms of raw materials and fuel equipment, exports products accounted for less, Brazil in the terms of raw materials and fuel equipment mainly relying on imports, and exports of mineral products are gradually declining in recent years.

\section{Brazil's major export products}

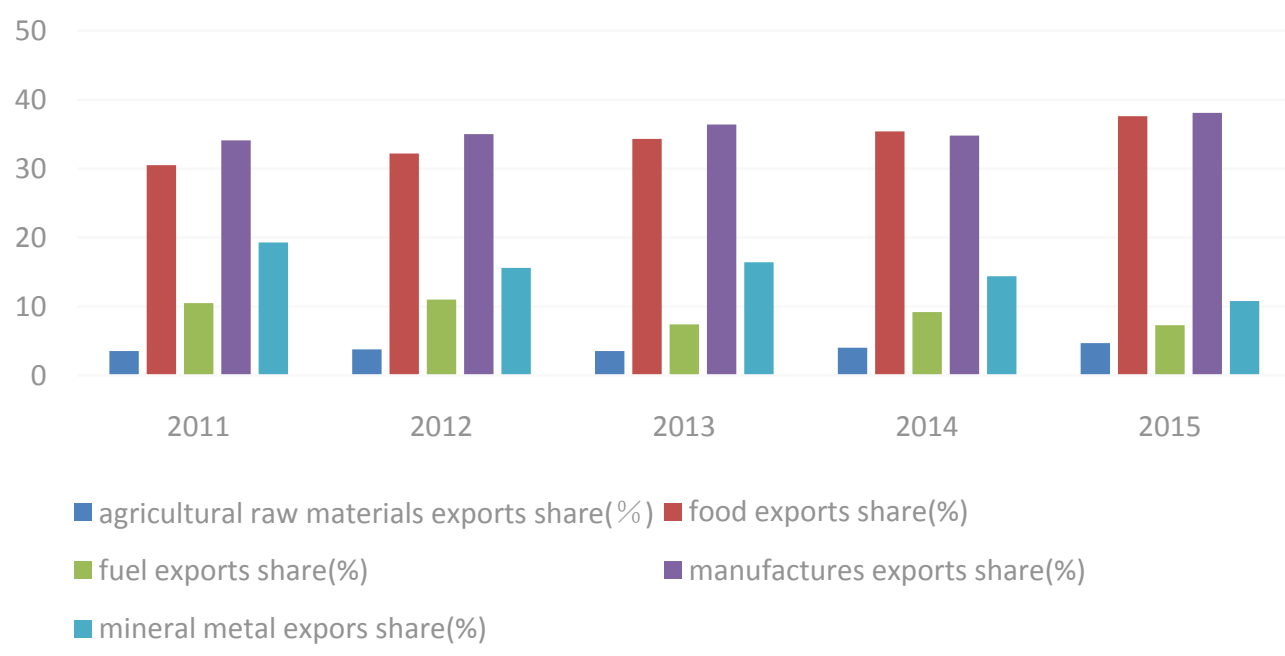

Figure 2.1: Brazil's major export products

**Data Sources: National Bureau of Statistics of China

\section{Russia}

Russia is the world's largest country. It is located in the eastern Europe and northern Asia, across the two continents of Europe and Asia. Because of the natural location and geographical advantages, Russia is rich in natural resources. It owns the world's largest reserves of mineral and energy resources, and it is the largest oil and gas exporter. 
As shown in Figure 2.2, Russia has a significant share of major export products. Because of the abundant mineral and energy resources. Russia's fuel exports account for more than $70 \%$ of its exports, while other exports account for a relatively small proportion, mainly rely on imports.

\section{Russia's major export products}

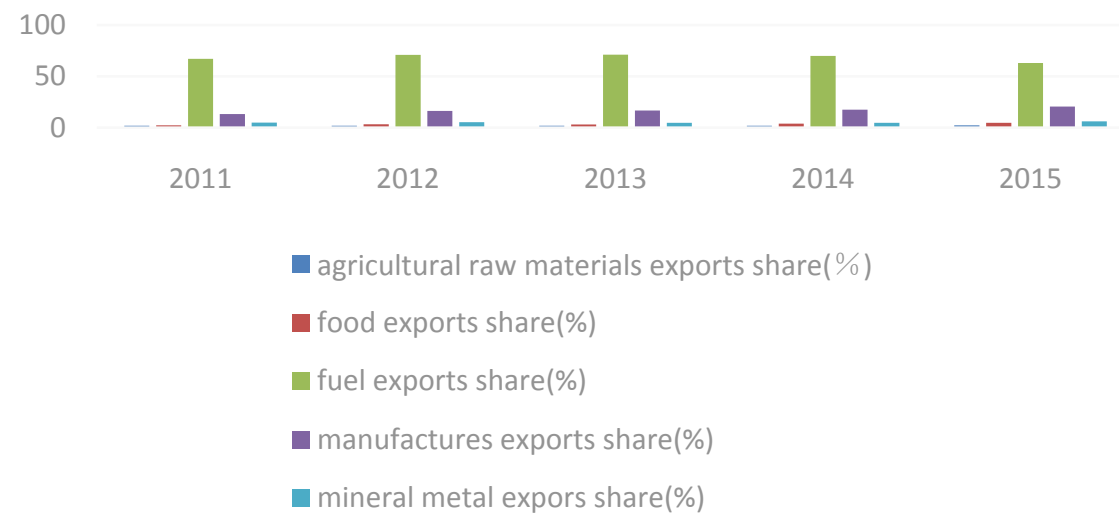

Figure 2.2: Russia's major export products

** Data Sources: National Bureau of Statistics of China

\section{South Africa}

South Africa is located in the southern hemisphere, it is the second largest economy in Africa. The standard of living of the people is high, and its economy is relatively stable compared to other African countries. South Africa is rich in mineral resources, and mining technology and other deep-mining technology are in a leading position in the world, mining is one of the pillar industries of South African national economy. As a big exporter of mineral resources, South Africa's exports have long relied on primary products, such as gold, masonry and sand, which made South Africa's manufacturing industry highly developed and manufacturing technology advanced. At the same time, because of its geographical advantages, South Africa's agriculture is also more developed. China is South Africa's largest trading partner, and South Africa is also China's largest trading partner in Africa.

As shown in Figure 2.3, South Africa's major export products are mainly manufactured goods and mineral metals, manufactured exports account for nearly $50 \%$, minerals and metals account for nearly $30 \%$.

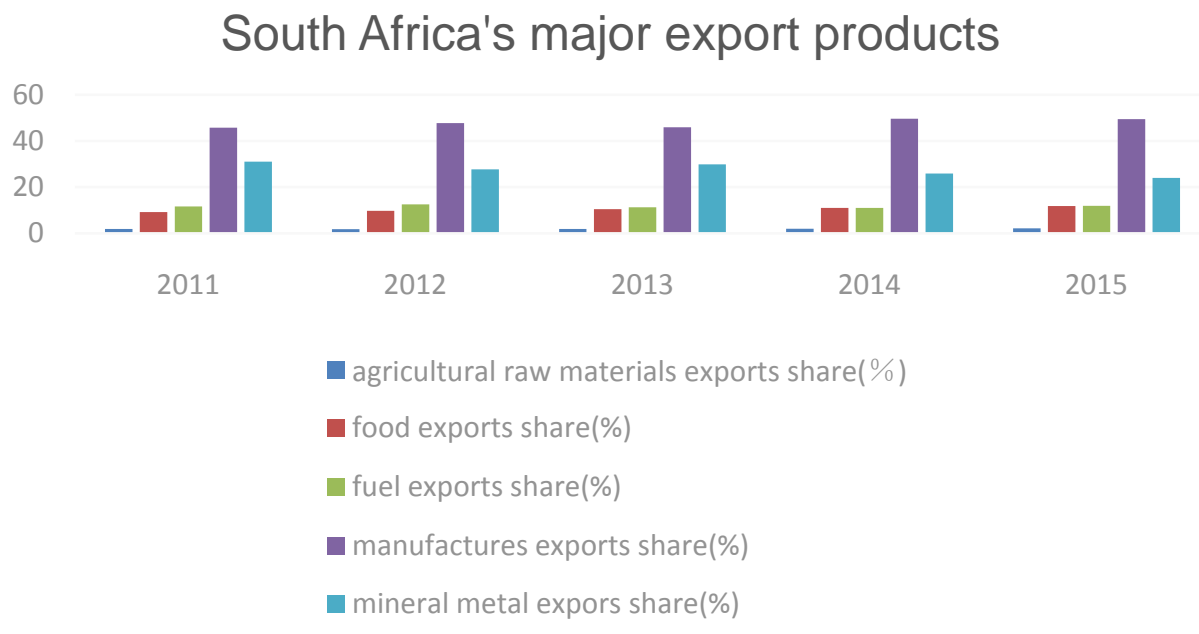

Figure 2.3: South Africa's major export products

** Data Sources: National Bureau of Statistics of China 


\section{India}

As one of the most important emerging economies in the world and one of the most influential powers in the South Asia and the Indian Ocean region, India occupies a significant position in global development and plays an important role in regional and international affairs. India is the second largest populous country in the world. In recent years, India's economy is developing rapidly and its economy is gradually diversified. However, due to its large population, India's economy is dominated by farming, modern agriculture, handicrafts, modern industry and its supporting industries. India's agricultural economy developed, which is one of the world's largest food producer. In the field of industry, its fields of steel, machinery, electricity, and chemistry are developed. The industry has formed a complete system.

As Figure 2.4 shows, most of India's major export products are manufactured goods, accounting for more than $60 \%$ of India's exports. In 2015, India's exports of manufactured goods accounted for $70 \%$ of the total exports.

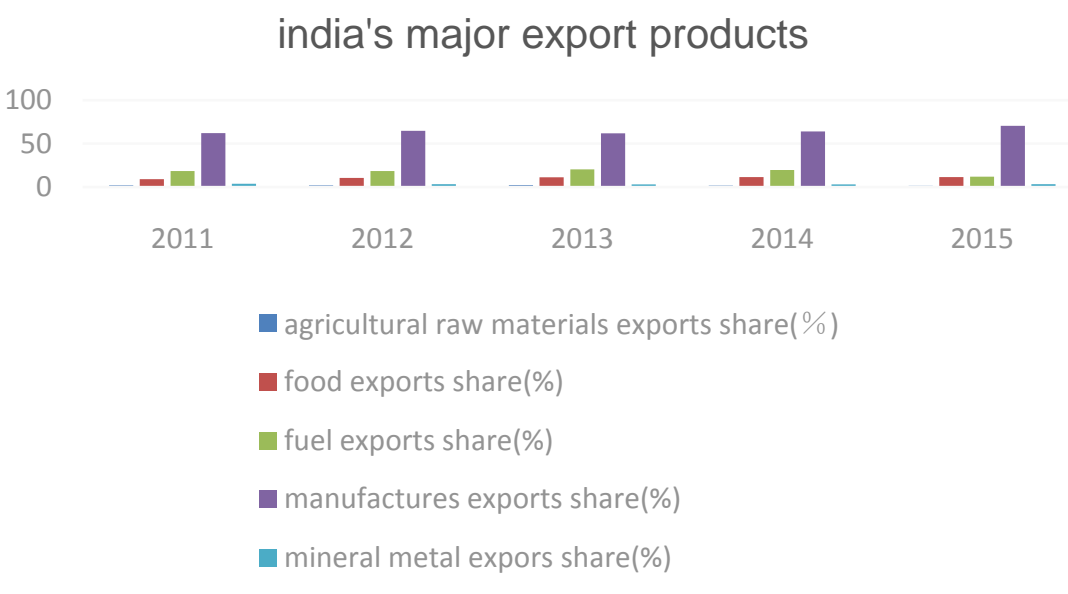

Figure 2.4: India's major export products

**Data Sources: National Bureau of Statistics of China

\section{Competitive Analysis}

Based on the display comparative advantage index formula, calculate the comparative advantage index of BRICS on agricultural products, service textiles, mechanical transport equipment and steel products.

(1) On the agricultural products, the RCA index of China and Russia is less than 1, indicating that the proportion of exporting agricultural products in China and Russia is less than the world's average, so there is no comparative advantage. Meanwhile, there is a downward trend of the comparative advantage on agricultural products in China while an upward trend in Russia. Moreover, the RCA value of Brazil on agricultural products is far greater than 1 , indicating that Brazil's share of agricultural exports is larger than the world's share of agricultural exports. Brazil has comparative advantages in the export of agricultural products. India and South Africa also have comparative advantages with RCA values larger than 1 . Therefore, these three countries are competitive on agricultural products, with competition among the three countries. Brazil's RCA value is above the level of 3 , indicating that Brazil, which is highly developed in agriculture and has a high proportion of agriculture product export, is significantly competitive in agriculture. In contrast, India and South Africa are relatively less competitive in this field.

(2) The value of RCA for clothing and textiles in Brazil, Russia, and South Africa is less than one, indicating that the share of exports of Brazil, Russia, and South Africa to clothing and textile is less than the world's share, that is, the three countries have no comparative advantage in clothing and textiles. The RCA value of China and India is greater than 1, indicating that China and India share more exports in clothing and textile than the world's share and have a comparative advantage. This 
shows that there is competition between China and India for clothing and textile. China is relatively stable in clothing and textile with an RCA value greater than 3 and gradually rising.

(3) On mechanical transport equipment, only China's RCA value is greater than 1, while Brazil, Russia, India and South Africa have less than 1 RCA on mechanical transport equipment. This shows that only China has a greater share of exports in exports of machinery and transportation equipment than the world's average. Brazil, Russia, India and South Africa have fewer exports in the area of machinery transportation equipment than the world's exports of machinery and transportation equipment. China has a comparative advantage in mechanical transportation equipment and is competitive in the world market. The RCA value has remained stable, while Brazil, Russia, India and South Africa have no comparative advantage in terms of mechanical transportation equipment.

(4) In the steel products, the RCA values of all five countries are greater than 1, indicating that the share of BRICS exports in the steel products is larger than the world's share of exports in the steel products and they are all competitive in the world market. There is a competitive relationship between the BRICS countries in the export of steel products and the competition is fierce. Russia's RCA value on steel products has an upward trend, indicating that the proportion of Russia's steel products exports and competitiveness is gradually rising. The competitiveness of the other four countries has a steady trend and South Africa holds the highest competitiveness of steel products.

Table 2-1: BRICS comparative advantage index

\begin{tabular}{|c|c|c|c|c|c|}
\hline \multicolumn{6}{|c|}{ agricultural products } \\
\hline & 2010 & 2011 & 2012 & 2013 & 2014 \\
\hline China & 0.43 & 0.38 & 0.37 & 0.35 & 0.35 \\
\hline Brazil & 4.05 & 3.72 & 3.83 & 4.01 & 4.23 \\
\hline India & 1.20 & 1.24 & 1.22 & 1.24 & 1.32 \\
\hline Russia & 0.48 & 0.78 & 0.81 & 0.86 & 0.88 \\
\hline South & 1.17 & 0.99 & 1.01 & 1.02 & 1.13 \\
\hline \multicolumn{6}{|c|}{ service textiles } \\
\hline & 2010 & 2011 & 2012 & 2013 & 2014 \\
\hline China & 3.06 & 3.59 & 3.47 & 3.38 & 3.58 \\
\hline Brazil & 0.36 & 0.03 & 0.32 & 0.29 & 0.15 \\
\hline India & 2.38 & 2.09 & 2.18 & 2.13 & 2.04 \\
\hline Russia & 0.02 & 0.03 & 0.03 & 0.02 & 0.03 \\
\hline South & 0.17 & 0.09 & 0.08 & 0.06 & 0.06 \\
\hline \multicolumn{6}{|c|}{ mechanical transport equipment } \\
\hline & 2010 & 2011 & 2012 & 2013 & 2014 \\
\hline China & 1.53 & 1.51 & 1.5 & 1.51 & 1.52 \\
\hline Brazil & 0.46 & 0.48 & 0.46 & 0.44 & 0.43 \\
\hline India & 0.58 & 0.47 & 0.38 & 0.4 & 0.48 \\
\hline Russia & 0.09 & 0.15 & 0.10 & 0.13 & 0.12 \\
\hline South & 0.46 & 0.52 & 0.51 & 0.53 & 0.54 \\
\hline \multicolumn{6}{|c|}{ steel products } \\
\hline & 2010 & 2011 & 2012 & 2013 & 2014 \\
\hline China & 1.21 & 1.01 & 1.02 & 1.01 & 1.01 \\
\hline Brazil & 1.16 & 1.69 & 1.67 & 1.56 & 1.48 \\
\hline India & 1.47 & 1.51 & 1.52 & 1.49 & 1.50 \\
\hline Russia & 1.10 & 2.30 & 2.31 & 2.33 & 2.37 \\
\hline South & 2.29 & 2.72 & 2.12 & 2.21 & 2.26 \\
\hline
\end{tabular}
$* *$ Data Sources: YuJuan Huang. Study on the Competitiveness and Complementarity of the Export Products in the
BRICS Countries[J].Business,2015(32):105-106. 


\section{Complementarity Analysis}

Through the analysis of the BRIC export trade structure, it is found that there are many differences between the BRICS exports, the export products are not similar, that is, there are strong product complementarities and potential trade opportunities in BRICs country.

\section{Complementary Within the Same Type of Product}

Complementary within the same type of products means that the import and export trade are complementary between the same type of products, when a country's export dominant product is another country's import dominant products, then the two countries are complementary.

Table 3-1: Brazil, Russia, India, China's major import and export volume

\begin{tabular}{|c|c|c|c|c|}
\hline \multirow[t]{2}{*}{ Brazil } & \multicolumn{2}{|c|}{ major export(billion dollars) } & \multicolumn{2}{|c|}{ major import(billion dollars) } \\
\hline & soybean & Iron ore & crude & diesel \\
\hline 2011 & & 319 & 141 & 74 \\
\hline 2012 & 172 & 238 & 134 & 66 \\
\hline 2013 & 228 & 260 & 163 & 83 \\
\hline 2014 & 233 & 200 & 155 & 87 \\
\hline 2015 & 210 & 104 & 74 & 34 \\
\hline \multirow[t]{2}{*}{ Russia } & \multicolumn{2}{|c|}{ major export(billion dollars) } & \multicolumn{2}{|c|}{ major import(billion dollars) } \\
\hline & crude & $\begin{array}{l}\text { crude oil } \\
\text { products }\end{array}$ & $\begin{array}{l}\text { fresh frozen } \\
\text { meat }\end{array}$ & drug \\
\hline 2011 & 1817.6 & 960.3 & 60.3 & 109.6 \\
\hline 2012 & 1809.3 & 1036.2 & 63.3 & 107.8 \\
\hline 2013 & 1736.7 & 1094.1 & 59.1 & 118.1 \\
\hline 2014 & 1539 & 1158.1 & 50.9 & 102.1 \\
\hline 2015 & 895.9 & 674.5 & 28.5 & 68.8 \\
\hline \multirow[t]{2}{*}{\begin{tabular}{|l|} 
India \\
\end{tabular}} & \multicolumn{2}{|c|}{ major export(billion dollars) } & \multicolumn{2}{|c|}{ major import(billion dollars) } \\
\hline & $\begin{array}{l}\text { clothing } \\
\text { accessories }\end{array}$ & $\begin{array}{l}\text { electronic } \\
\text { machinery parts }\end{array}$ & fossil fuels & $\begin{array}{l}\text { pearl precious } \\
\text { stones precious } \\
\text { metals }\end{array}$ \\
\hline 2011 & 137.4 & 115.3 & 1727.5 & 910.8 \\
\hline 2012 & 129.6 & 108.6 & 1813.5 & 839 \\
\hline 2013 & 150 & 103 & 1813.8 & 584.6 \\
\hline 2014 & 168.4 & 87 & 1564 & 623.8 \\
\hline 2015 & 169.9 & 80 & 969.5 & 565.4 \\
\hline \multirow[t]{2}{*}{ China } & \multicolumn{2}{|c|}{ major export(billion dollars) } & \multicolumn{2}{|c|}{ major import(billion dollars) } \\
\hline & \begin{tabular}{|l} 
electrical \\
equipment
\end{tabular} & mechanical parts & $\begin{array}{l}\text { electrical } \\
\text { equipment }\end{array}$ & $\begin{array}{l}\text { Fossil fuel, } \\
\text { mineral oil }\end{array}$ \\
\hline 2011 & 4457.6 & 3537.6 & 3509.5 & 2758.1 \\
\hline 2012 & 4873.2 & 3758.9 & 3815.2 & 3131.3 \\
\hline 2013 & 5612.9 & 3831.5 & 4394.2 & 3152.3 \\
\hline 2014 & 5709.2 & 4008.3 & 4243.2 & 3167.9 \\
\hline 2015 & 5943.3 & 3642.8 & 4286.9 & 1986 \\
\hline
\end{tabular}

**Data Sources: BRICS Joint Statistical Manual (2017) 
Table 3-2: South Africa's main import and export product ratio

\begin{tabular}{|c|c|c|c|c|}
\hline \multirow[t]{2}{*}{ South Africa } & \multicolumn{2}{|c|}{ main export(ratio) } & \multicolumn{2}{|c|}{ main import(ratio) } \\
\hline & manufactures & mineral metal & manufactures & fuel \\
\hline 2011 & 45.7 & 31 & 63.5 & 20.8 \\
\hline 2012 & 47.7 & 27.7 & 61.8 & 22.1 \\
\hline 2013 & 45.9 & 29.9 & 63.3 & 21.6 \\
\hline 2014 & 49.6 & 25.9 & 61.1 & 23.4 \\
\hline 2015 & 49.4 & 24 & 64.5 & 17.6 \\
\hline
\end{tabular}

** Data Sources: National Bureau of Statistics of China

Due to the lack of South Africa's main import and export product volume data, so trade complementarity between the South Africa and other BRICS country measured by main import and export products accounted for total import and export products. As Table 3-1 and Table 3-2 show, Brazil and South Africa complement each other on agricultural products. Brazil can export agricultural products such as soybeans, coffee and sugar compounds to South Africa. South Africa can export food products and tobacco to Brazil. Brazil and Russia complement each other on crude oil products. China and South Africa complement each other in steel and mineral products. In the mechanical transport equipment. Both China and India produce and export electrical and electronic equipment, but the uses of products are different between two countries, so they can complement each other.

\section{Complementary between Different Types of Products}

Through the analysis of the export product structure of the BRICS countries, we can see that there are many products that can form the complementary relationship among different countries.

Table 4-1: BRICS countries import and export comparative advantage

\begin{tabular}{|l|l|l|l|l|}
\hline & $\begin{array}{l}\text { agricultural } \\
\text { products }\end{array}$ & service textiles & $\begin{array}{l}\text { mechanical transport } \\
\text { equipment }\end{array}$ & steel products \\
\hline $\begin{array}{l}\text { Export } \\
\text { advantage }\end{array}$ & $\begin{array}{l}\text { Brazil, India, } \\
\text { South Africa }\end{array}$ & China, India & China & $\begin{array}{l}\text { China, Brazil, Russia, } \\
\text { India, South Africa }\end{array}$ \\
\hline $\begin{array}{l}\text { Import } \\
\text { advantage }\end{array}$ & China, Russia & $\begin{array}{l}\text { Brazil, Russia, } \\
\text { South Africa }\end{array}$ & $\begin{array}{l}\text { Brazil, Russia, India, } \\
\text { South Africa }\end{array}$ & \\
\hline
\end{tabular}

** Data Sources: Based on the above analysis

As shown in Table 4-1, China can form a complementary relationship with Brazil and South Africa. China has comparative advantages in exporting service textiles and mechanical transport equipment. Brazil and South Africa has not comparative advantages in exporting service textiles and mechanical transport equipment, so China can export service textile products or mechanical transport equipment products to Brazil and South Africa. Brazil and South Africa have the comparative advantage in exporting agricultural products. China has not comparative advantage in exporting agricultural products, so Brazil and South Africa can export agricultural products to China, and both sides can form trade complementarities.

\section{Conclusion}

(1)The BRICS countries are the fastest-growing emerging economies in the world. The economy and trade have developed rapidly since BRICS countries set up. With the social economic development and the progress of economic globalization, the status of BRICS countries in the world trade pattern is gradually rising, especially after the financial crisis in 2008, the world economy and trade tended to develop steadily. BRICS seized the opportunity for development and improved the international influence. So it is important to deepening the cooperation among BRICS countries.

(2)The above analysis shows that there are some competition between the BRICS countries in 
exporting products. On agricultural products, because of natural rich natural resources, Brazil has strong competitiveness in agricultural products and competes with India and South Africa. There is a strong competitive relationship between China and India in service textile products. Both China and India are populous countries, their labor resources are abundant and the advantages are obvious. They both are labor-intensive countries, therefore the textile and other industries are relatively developed, competition is fierce in the two countries. In the mechanical transport equipment, China has a strong export advantage and does not compete with other BRICS countries. In the steel products, BRICS countries have the export advantage, so competition is fierce in the five countries.

(3)BRICS countries have different comparative advantages in natural resources. Therefore, BRICS countries not only have the competition, but also have the stable complementary relationship, especially between China and Brazil and South Africa. China has a well-developed in service textiles industry. Brazil and South Africa have a well-developed in manufactured goods industry, so they have comparative advantages in export of agricultural products. Therefore, Brazil and South Africa formed a strong closer complementary relationship with China.

\section{Summary}

\section{Status}

(1) With the progress of economic globalization, the pattern of the world economy has become increasingly complicated, and the economic cooperation among BRICS countries has also entered a new phase. With the improvement of the overall economic strength and the enhancement of international status, the BRICS countries have obtained substantive achievements by cooperating with each other in safeguarding the rights and interests of developing countries, resolving major international events and advancing the changes in the world economic structure in the capacity of an emerging interest community. Against the background of the new round of global governance reform and industrial technology revolution, all countries in the world have formulated and adjusted their national economic development strategies. The BRICS countries are facing new opportunities as well as challenges and competitions. Therefore, although there are competition and complementarity between the BRIC countries in export trade, the trade is generally not yet close enough with a great deal of potential for cooperation.

(2) As the largest developing country and the most dynamic economic region in the world, China plays leading role in the cooperation and development of BRIC countries. The trade between China and the other four countries accounts for $90 \%$ of the total amount between the five countries. China is also the largest trading partner of Brazil, Russia, and South Africa and one of India's major trading partners. As the chair of the 2017 BRICS countries, China further consolidated its cooperation consensus on the theme of "Stronger Partnership for a Brighter Future" and promoted the BRICS cooperation in various fields in the future.

\section{Suggestion}

(1) It can be seen from the above analysis that the product mix of the BRICS exports is relatively simple. Most of the export products are resource-based, low-tech and labor-intensive products, while the exports of medium- and high-tech and capital-intensive products are relatively small. Therefore, BRICS countries need to speed up the optimizationand upgrading of their industrial structure, introduce foreign investment and advanced technology and equipment, develop capital-intensive and technology-based products, and gradually replace existing labor-intensive industries with capital-technology-intensive industries to improve the competitiveness of export product. Meantime, enhancing trade between BRICS is also an important approach to gain common development.

(2) With the full use of the comparative advantages between BRICS countries, the BRIC cooperation mechanism should be deepen to realize the integrated development of trade competition and cooperation. The BRICS countries, representatives of emerging economy and industry in the world, have the same interest demands and comparative advantages of export commodity structure 
in the international market, which constitute the foundation for BRICS cooperation. In addition, since the BRICS come from different regions and their cultural differences have a significant impact on the export trade and economic development mode, the BRIC countries should first strengthen their economic partnership among member countries and actively carry the all-around multilateral cooperation in political, economic, cultural and trade fields, deepen the cooperation mechanisms and promote the integrated development of the BRICS countries in the global economic context.

\section{References}

[1] Yujuan Huang. Study on the Competitiveness and Complementarity of the Export Products in the BRICS Countries[J].Business,2015(32):105-106.In Chinese

[2] Baichuan Sang, Wei Zheng. Research on How to Expand Service Trade Between China and BRICS Countries__ based on trade competitiveness and complementarity[J].Word Economy Studies,2014(6):30-34.In Chinese

[3] Yuming Cui, Mei Li, Yahui Zhao. Study on the Competition and Complementation of BRICS Countries' Trade_-based on Exponential Model comparison[J].Shandong Social Sciences,2015(4):87-91.In Chinese

[4] Liang Xu. Dynamic Analysis Based on the Comparative Advantage of China and "the Belt and Road Initiatives”[J].Management World,2016,No.269(2):170-171.In Chinese

[5] Yaqin Chen. Trade Complementarity Between China and One Belt and One Road Countries__ Based on Chronological Data Analysis with Comparative Advantage[J].Journal of Jixi University,2016(10).In Chinese

[6] Hongliang Ma. Study on Trade Complementarity in BRICS Countries [D]. GanSu:Lanzhou University of Finance and Economics,2012.In Chinese

[7] Jingyun Wu. Competition or Complementarity? An Empirical Study on Economic Relationship among "BRICS"[J].International Business: Journal of University of International Business and Economics,2012 (2) :21-30.In Chinese

[8] Rong Cheng, Huifang Cheng. Sino-Indian trade relations:competition or complementarity--A Whole Perspective Analysis Based on Commodity Trade and Service Trade[J].Journal of International Trade,2011,(6).In Chinese

[9] Salman Khan,2010. Crude Oil Price shocks to Emerging Markets: Evaluating the BRICs Case. MPRA Paper. 2010(4),NO.22978.

[10] Misa Takebe, Montfort Mlachila, 2011. FDI from BRICs to LICs: Emerging Growth Driver?. IMF Working Paper. 2011( 7) : No.11/178. 